\title{
Latin America's Decontamination and Decommissioning Needs
}

\author{
Final Report \\ August 6, 1997
}

By:
M. A. Ebadian; J. Valverde Bermudez
L. E. Lagos; M. Mayerle

Work Performed Under Contract No.: DE-FG21-95EW55094

For

U.S. Department of Energy

Office of Fossil Energy

Federal Energy Technology Center

P.O. Box 880

Morgantown, West Virginia 26507-0880

By

Florida International University

Hemispheric Center for Environmental Technology (HCET)

Center for Engineering \& Applied Sciences

10555 West Flagler Street

EAS-2100

Miami, Florida 33174 


\section{Disclaimer}

This report was prepared as an account of work sponsored by an agency of the United States Government. Neither the United States Government nor any agency thereof, nor any of their employees, makes any warranty, express or implied, or assumes any legal liability or responsibility for the accuracy, completeness, or usefulness of any information, apparatus, product, or process disclosed, or represents that its use would not infringe privately owed rights. Reference herein to any specific commercial product, process, or service by trade name, trademark, manufacturer, or otherwise does not necessarily constitute or imply its endorsement, recommendation, or favoring by the United States Government or any agency thereof. The views and opinions of authors expressed herein do not necessarily state or reflect those of the United States Government or any agency thereof. 


\section{DISCLAIMER}

Portions of this document may be illegible in electronic image products. Images are produced from the best available original document. 
1. INTRODUCTION

2. PROJECT DESCRIPTION

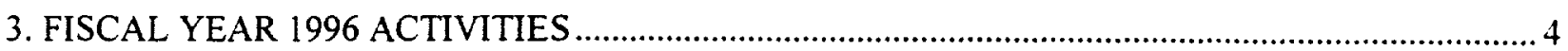

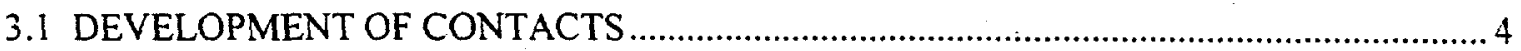

3.2 SIGNING OF THE DOE-CNEA TECHNOLOGY COOPERATION AGREEMENT

3.3 JOINT COORDINATING COMMITTEE ON RADIOACTIVE AND MIXED WASTE MANAGEMENT (JCCRM) WORKSHOP ........................................ 5

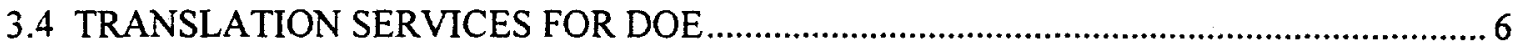

3.5 PARTICIPATION IN SPECTRUM '96: AN INTERNATIONAL TOPICAL MEETING ON NUCLEAR AND HAZARDOUS WASTE MLANAGEMENT ........................ 7

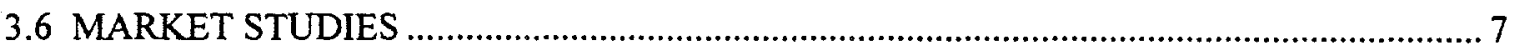

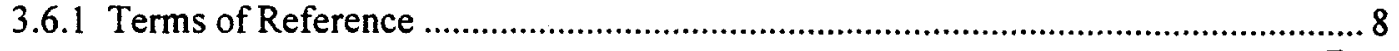

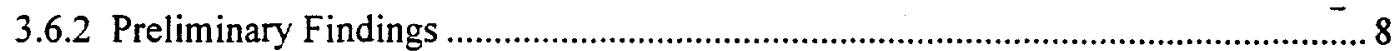

4. FISCAL YEAR 1997 PLANNED ACTIVITIES RELATED TO THIS PROJECT ..........................11

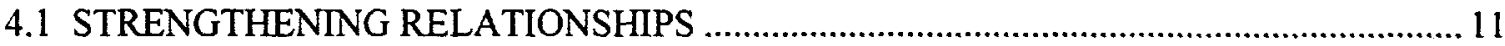

4.2 EXPANDING THE CONTACT DATABASE ............................................................. 11

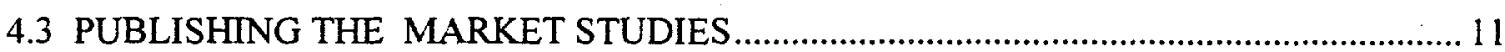

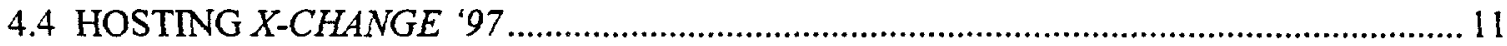

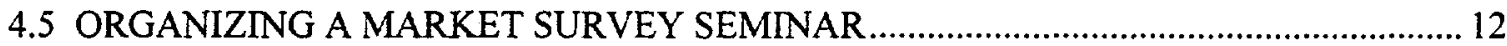

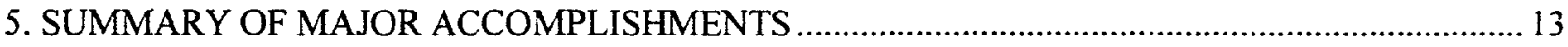

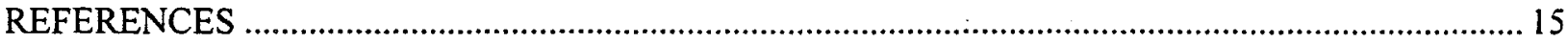

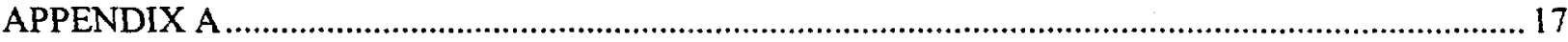

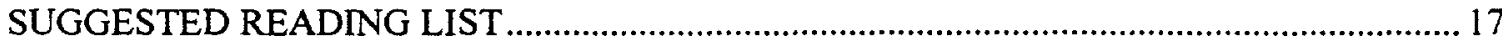

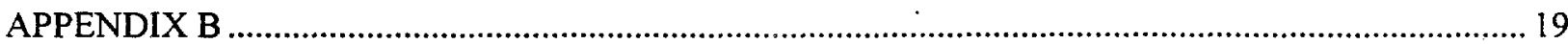

ENVIRONMENTAL INSTITUTIONS IN ARGENTINA, BRAZIL, AND

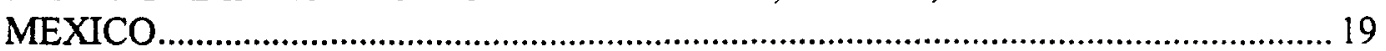

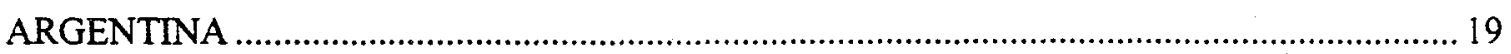

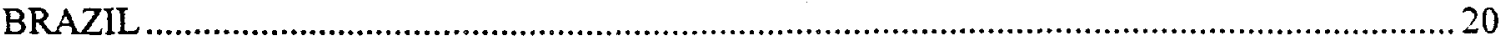

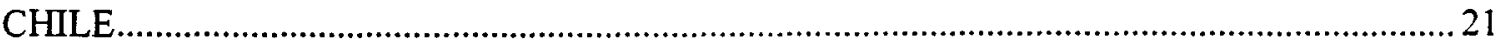

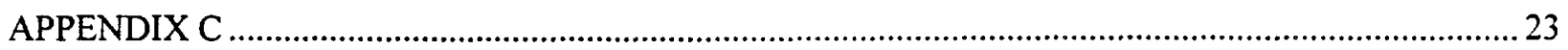

THE ENVIRONMENTAL TECHNOLOGY MARKET IN LATIN AMERICA: AN OVERVIEW 


\section{INTRODUCTION}

The nations of Latin America and the Caribbean have experienced profound change since the tumultuous decades of the 1970s and 1980s. These changes include the return of formal democracy, the implementation of economic reform and stabilization, the embrace of free trade, and an ever-growing awareness of the need for environmental regulation, protection, and remediation. This new concern for the environment reflects not only the dramatic political changes the region has experienced over the past fifteen years but, more significantly, societal change and the structural economic transformation of many of the nations into open, exportoriented economies.

Environmental protection has gained importance as a result of economic growth, citizen activism, and the recognition by the public and private sector of the latent lucrative market for environmental goods and services in Latin America and the Caribbean. This is evidenced in new and stricter environmental laws and regulations that have been passed throughout the region. These laws and regulations have given rise to fast growing markets for environmental technologies in countries such as Mexico, Brazil, Chile, and Argentina.

In Argentina, the new constitution (1994) guarantees the right of the individual to a clean and healthy environment. In Mexico, law enforcement capabilities have increased with the creation of the Federal Attorney General's Office for the Environment. In Chile, the 1994 Basic Environmental Law promotes efficiency and pollution prevention by assessing the costs of pollution to the polluter.

Further evidence of this growth is reflected in two important legal developments that will greatly affect the market for hazardous waste management services in Mexico. Effective January 1, 1999 , foreign investors will be allowed to participate up to 100 percent in the capital stock of Mexican corporations involved in environment-related activities. That same year, the maquiladora ${ }^{1}$ industry will be required to treat and dispose of hazardous waste in Mexico rather than ship it to the United States. If these schedules hold, the market for environmental goods and services (consulting, waste management, financing, etc.) in Mexico will have added impetus. In addition, stricter law enforcement and greater institutional capacity of oversight agencies have reinforced and continuously fed this process.

Despite the fact that environmental markets such as Mexico's were expected to grow by as much as 7.5 percent in 1996 and reach growth rates as high as 10 percent by 1998 (American Embassy, U.S. and Foreign Commercial Service 1995), little systematic, in-depth research has been conducted. Therefore, the Hemispheric Center for Environmental Technology (HCET), in conjunction with the Latin American and Caribbean Center (LACC), at Florida International University, initiated a comprehensive research program on sustainable development, environmental protection, and the market for environmental technologies in Latin America and the Caribbean. Its aim was to identify existing and emerging markets for environmental

A Mexican assembly or manufacturing operation that can be subject to up to 100 percent non-Mexican ownership. Most maquiladoras are located along the Mexican-U.S. border. 
technologies in Latin America, focusing primarily on legal, political, and economic conditions and factors that favor or hinder, investment in the environmental sector. 


\section{PROJECT DESCRIPTION}

This project commenced on October 1, 1995 (FY96).

The project's purpose was to identify the Latin American and Caribbean countries that have the most mature and lucrative markets for environmental goods and services, the markets that have the greatest growth potential, and the countries that exhibit the greatest openness to trade in this sector. The program also intended to determine, by scope and severity, the most important environmental needs in each of these markets; the types of solutions used or being considered to satisfy these needs; and the most important players, both private and public, in each country. In addition, the Latin American and Caribbean program intends to identify other emerging markets that exhibit the potential for future growth and development once their formative stage is complete.

Initially, the project emphasized developing contacts with academics, businesspersons, government officials, and others currently working on or researching issues related to sustainable development and environmental technology in Latin America. These individuals assisted in identifying the most salient environmental issues that require applied environmental technology in Latin America and the Caribbean. 


\section{FISCAL YEAR 1996 ACTIVITIES}

\subsection{DEVELOPMENT OF CONTACTS}

The first task completed in FY96 was the development of relationships with multiple national and international agencies related to or working in Latin America. The intent was to promote collaboration and obtain economic, political, social, legal, and environmental data from these entities. The following institutions are those with which HCET and LACC have established a collaborative relationship:

Argentine National Atomic Energy Commission (Comisión Nacional de Energía Atómica, CNEA)

The Chilean Consulate, Miami

Economic Commission for Latin America and the Caribbean

The Economist Intelligence Unit

Environmental Protection Agency (EPA)

Instituto Ambiental, Chile

Instituto Tecnológico de Monterrey, Mexico

InterAmerican Development Bank

The Mexican Consulate, Miami

National Trade Data Bank

United Nations Environment Programme

Universidad de las Américas, Puebla, Mexico

Universidad Anahuac del Sur, Mexico City

Universidad Autónoma del Carmen, Campeche, Mexico

Universidad de Belgrano, Argentina

Universidad de Buenos Aires

Universidad de Chile

Universidad Iberoamericana, Mexico City

Universidad Nacional de Lomas de Zamora, Argentina

Universidad Regiomontana, Nuevo León, Mexico

Universidad Tecnológica de Córdoba, Argentina

Universidad Veracruzana, Veracruz, Mexico

U.S. Department of Commerce

The World Bank

In addition, HCET has identified the principal companies and institutions that are conducting environmental research and work in Argentina, Brazil, Chile, and Mexico. A sample listing is provided in Appendix B. 


\subsection{SIGNING OF THE DOE-CNEA TECHNOLOGY COOPERATION AGREEMENT}

On May 29, 1996, FIU-HCET hosted the signing of the Implementing Arrangement between the Department of Energy of the Lnited States of America and the National Atomic Energy Commission (Comisión Nacional Energia Atómica) of the Argentine Republic for Technical Exchange and Cooperation in the Area of Radioactive and Mixed Waste Management. This event not only marked the beginning of a new era of cooperation between both countries but also positioned HCET and Florida International University (FIU) to take a leading role in facilitating the exchange of technology between the United States and Argentina and, in a larger context, between the United States and Latin America.

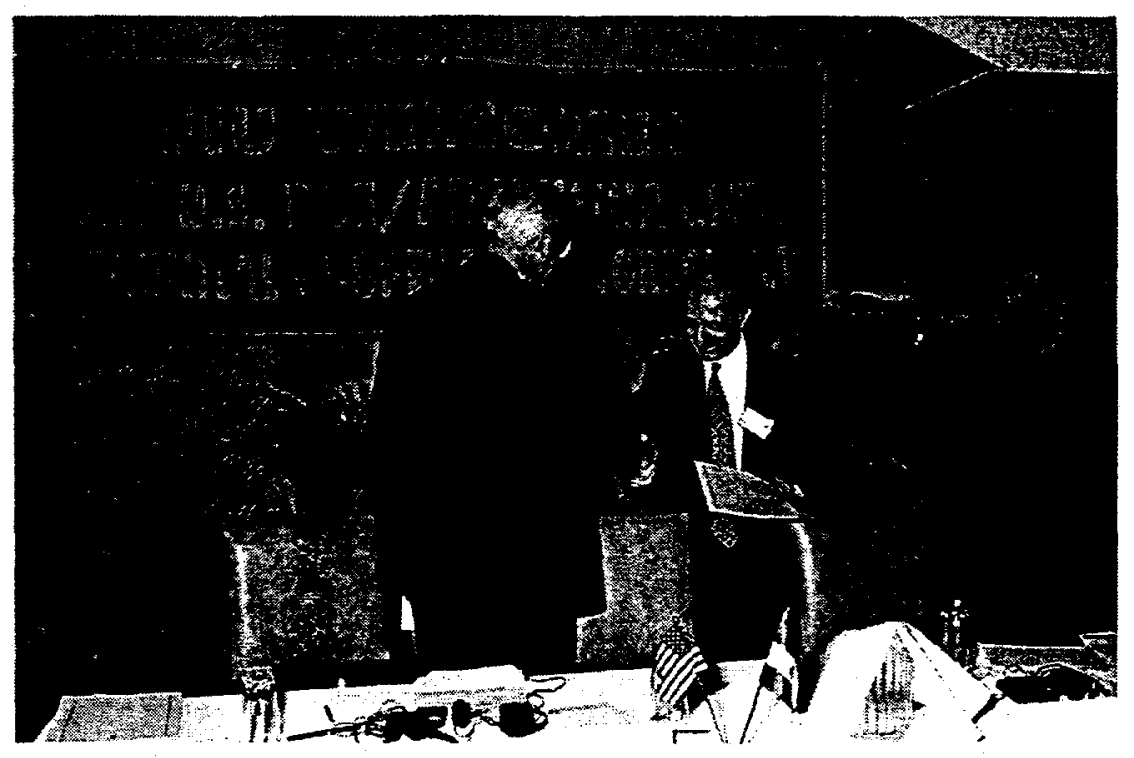

Figure 1. Signing of the DOE-CNEA agreement. Pictured from left to right are Dr. Clyde Frank, Deputy Assistant Secretary for the Office of Science and Technology, U.S. Department of Energy and Dr. Eduardo F. Santos, Director, Board of Directors, Argentine National Atomic Energy Commission.

To allow U.S. industry to benefit from FIU's links to Latin America and the Caribbean, DOE's Office of Science and Technology has designated HCET as its principal technology transfer agent for this region. This selection was based on FIU's and HCET's continuous records of high performance in its research and development (R\&D) work conducted for DOE.

\subsection{JOINT COORDINATING COMMITTEE ON RADIOACTIVE AND MIXED WASTE MANAGEMENT (JCCRM) WORKSHOP}

Immediately after this historic signing, FIU-HCET hosted the first Joint Coordinating Committee on Radioactive and Mixed Waste Management (JCCRM) meeting between the U.S. Department of Energy and the National Atomic Energy Commission of Argentina (CNEA). As a result of 
this workshop, three main areas of potential cooperation of interest to the Argentine delegation were defined. These are

1. Remediation of uranium mill tailings;

2. Decontamination ànd decommissioning; and

3. Research and development in the field of low-level and high-level waste management.

\subsection{TRANSLATION SERVICES FOR DOE}

Per the request of the U.S. Department of Energy, HCET translated DOE's remediation technology information cards into Spanish (see Figure 2). The translation of these technology information cards allows the Latin American and Caribbean community to gain a better understanding of the latest environmental technologies. The cards were first introduced at the signing of the Technology Cooperation Agreement between the DOE and Argentina's National Atomic Energy Commission on May 29, 1996. They have been made available at other events, including Spectrum '96. The Spanish language Technology Information Cards may be obtained by calling 1-800-736-3282.
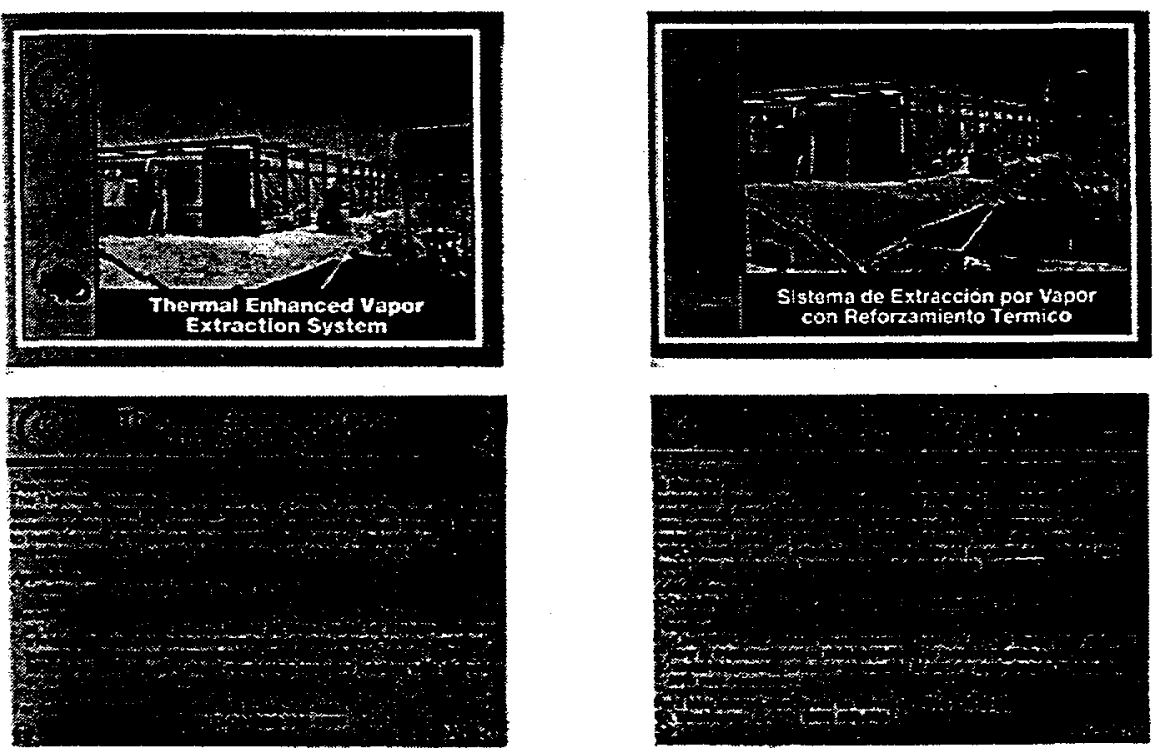

Figure 2. Samples of the translated technology information cards. The original English version is on the left; the Spanish translation prepared by HCET is on the right. 


\subsection{PARTICIPATION IN SPECTRUM '96: AN INTERNATIONAL TOPICAL MEETING ON NUCLEAR AND HAZARDOUS WASTE MANAGEMENT}

In August 1996, several members of the HCET team attended Spectrum '96. Four poster sessions and a full paper on the environmental technology market in Latin America were presented at this conference. The latter (see Appendix C) provides a general overview of factors affecting the development and potential for growth of the market for environmental technologies in Latin America. The paper presents the following conclusions (Valverde-Bermúdez 1996):

- Mexico and Chile have the most advanced environmental legislation and enforcement mechanisms in the region. They are therefore two of the markets with the greatest potential;

- In Mexico, approximately 90 percent of all hazardous waste is released into the environment without proper treatment; and

- In Chile, economic growth allows waste generating industries to afford the acquisition of pollution prevention and waste handling equipment. This, in turn, stimulates growth in the market for environmental goods and services.

In addition, a panel featuring speakers from Mexico and Argentina was organized by the Latin American Coordinator and chaired by Dr. M.A. Ebadian, HCET's Executive Director, and Roger Gilchrist, Technology Demonstration Manager for the Westinghouse Hanford Company. The principal topics covered in this panel were 1) the legal, political, economic, and cultural factors affecting environmental regulation and 2) the market for environmental goods and services in Argentina. The panelists also addressed issues of environmental remediation in Mexico, including the National Institute of Ecology's (Instituto Nacional de Ecologia, INE) vision for the future; the Mexican Petroleum Institute's (Instituto Mexicano del Petróleo, IMP) current environmental practices and needs; and Lucent Technologies de México's application of Lucent Technologies' Global Environmental Standards to their plants and processes in Mexico.

\subsection{MARKET STUDIES}

Through various studies conducted in conjunction with the Latin American and Caribbean Center (LACC) and the Summit of the Americas Center (SOAC), HCET identified nuclear and hazardous waste management, municipal and solid waste management, air pollution control and prevention, and water treatment as the most important environmental concerns in Latin America. The significance of each of these needs varies from one country to another; however, for the region as whole, these waste management areas pose the most important challenges and the best investment opportunities.

Through further investigation, the HCET/LACC team identified Argentina, Brazil, Chile, and Mexico as having the most significant and lucrative environmental technology markets in the region.

As a result, comprehensive market studies were commissioned in each of these four countries. In each case, HCET has worked with institutions and/or individuals that are regarded as the best in their field. In Mexico, HCET is working with Market Strategies International (MSI), one of only 
two firms authorized by the Mexican government to translate and publish its environmental laws and regulations into English. In Chile, HCET is working with the Center for Public Policy Analysis, considered to be the leading think tank on sustainability in that country. In Argentina, HCET is working with a team of experts led by Dr. Jorge Franza, a well-known author on environmental law in Argentina.

Individually and collectively, these studies represent the first concerted effort to present a series of in-depth, country-specific analyses. As noted earlier, all studies will be published in 1997.

\subsubsection{Terms of Reference}

The market studies will cover the following issues as per the terms of reference developed by LACC, SOAC, and HCET:

- Main aspects of the market for environmental goods and services;

- Economic, political, and legal factors affecting market growth and development as well as environmental policies and regulations;

- Structure, trends, and performance of the market and key market segments;

- Size and relevance of the environmental market relative to the entire economy (including a reference to the performance of other economic sectors);

- Identification of the most important environmental problems, organized categorically by scope, severity, and remediation needs;

- Identification of commercial opportunities, especially in the following segments: hazardous and nuclear waste management, solid and municipal waste, and wastewater treatment. Special attention will be paid to monitoring, characterization, and the control and reduction of pollutants;

- Identification of the most common contaminants (e.g., organic compounds and heavy metals) found in industrial and municipal effluents, emissions, and discharges, including concentration levels and the severity of the risk they pose;

- Openness of the environmental sector to foreign direct investment (FDI) and foreign trade, including relevant information on investment and trade policies affecting the environmental market; and

- Identification of the most important players, both domestic and foreign, in this market.

\subsubsection{Preliminary Findings}

HCET has found that the four identified countries have a need for pollution prevention, end-ofpipe remediation, and infrastructure technologies. Most governmental spending related to the environment is supported by funds from international financial institutions (IFIs) such as the World Bank and the InterAmerican Development Bank. It is geared primarily toward infrastructure and remediation projects such as the construction of water treatment and delivery systems as well as sites for the characterization, management, storage, stabilization, and the final 
disposal of hazardous and radioactive waste.

Environmental spending by the private sector is primarily oriented toward pollution prevention and end-of-pipe solutions. This is the result of stricter environmental laws and regulations, the environmental protection institutions' having greater law enforcement capabilities, consumer demands for cleaner production methods, and, in the case of exporters, the need to comply with environmental production standards imposed by the governments that regulate their target markets. Furthermore, liberalization of trade, the harmonization of customs procedures and environmental regulations, the reinforcement of intellectual property protection, and the deregulation and harmonization of rules applying to the energy sector should provide greater opportunities for investment for companies involved in environmental technology goods and services.

In these and other Latin American countries, market growth is driven not only by increasing regulations and IFI-funded projects but also by the Miami Process, a hemispheric commitment made by the nations' leaders at the Summit of the Americas held in Miami in December 1994 to complete the negotiation of the Free Trade Area of the Americas (FTAA) by 2005. During the last trade ministerial, held in Cartagena de Indias, Colombia on March 18-21, 1996, the recommendations of the private sector to the governments of the Western Hemisphere made it evident that trade, investment, economic deregulation, and environmental protection will move in tandem as they drive the hemispheric integration process. The following proposals put forth by the business sector at this ministerial illustrate this point (Ministerio de Comercio Exterior de Colombia 1996):

- The process of economic reform and deregulation must be maintained;

- There must be mechanisms for the effective implementation of World Trade Organization (WTO) agreements on customs procedures. In addition, these procedures should be harmonized across the hemisphere;

- More effort is needed regarding the creation of a Customs Union;

- Harmonized rules on intellectual property protection are needed to strike a balance between intellectual property rights and the transfer of technologies;

- Investment in the energy sector will require the creation of stable monetary systems and regulatory frameworks that are compatible across countries and energy forms;

- Similar standards and regulations should be applied to the oil, gas, and electric energy segments.

- Trade and environmental protection can be pursued simultaneously, but this requires that they be linked;

- Environmental regulations must not be used as a disguise for trade protection;

- Conditions must be created to promote private sector solutions to environmental problems;

- Provide tax incentives to those institutions or firms that implement environmental technology solutions; 
- Harmonization of environmental rules should be gradual to allow less developed countries undergo a transitional period; and

- Transfer of technology should strengthened.

Although all market studies are being guided by the same basic terms of reference, we can expect them to be dissimilar in their final form as a result of the very different social, cultural, legal, economic, and political contexts within which each domestic market functions and develops. 


\section{FISCAL YEAR 1997 PLANNED ACTIVITIES RELATED TO THIS PROJECT}

\subsection{STRENGTHENING RELATIONSHIPS}

In Fiscal Year 1997, HCET will focus on strengthening and cementing the contacts that were developed in association with this project during HCET's first year of operation. In addition, HCET will continue its research on the economic, political, and legal factors affecting the growth of the environmental sector.

\subsection{EXPANDING THE CONTACT DATABASE}

HCET will continue the process of populating the information system with data on environmentrelated institutions and organizations in Latin America and the Caribbean. The entities will be categorized according to their type of activity (e.g., financing, regulation, consulting, engineering, etc.) and their scope (e.g., regional, national, governmental, non-governmental, profit, non-profit, etc.) This database will be made available to external users in 1997. A sample of the information contained therein is presented in Appendix B.

\subsection{PUBLISHING THE MARKET STUDIES}

The previously mentioned environmental technology market studies on Argentina, Brazil, Chile, and Mexico will be concluded and published along with a fifth study examining the environmental technology market of Spain.

\subsection{HOSTING X-CHANGE '97: THE GLOBAL D\&D MARKETPLACE}

In December 1997, HCET will host X-change '97: The Global D\&D Marketplace, an international symposium on nuclear and hazardous waste management. During this five-day symposium, participants will investigate emerging environmental technologies and other innovations that promise to reduce the cost of decontaminating and decommissioning buildings and equipment at nuclear sites and other facilities that handle hazardous materials.

$X$-change ' 97 is both a process and an event designed to foster partnerships between D\&D problem holders and $\mathrm{D} \& \mathrm{D}$ technology providers with additional participation from the investor and stakeholder community. Among those represented will be international governments and companies, the U.S. Department of Energy, the U.S. Department of Defense, commercial nuclear industries, technology suppliers, universities, national laboratories, and contractors. At the conference, technology demonstrations will the provide first-hand information to permit decisionmakers to implement new, more cost-effective D\&D strategies. The technical sessions will explore cutting-edge technologies and research findings that produce bottom-line improvements in cost and performance. 


\subsection{ORGANIZING A MARKET SURVEY SEMINAR}

As a part of $X$-change '97, FIU-HCET will organize a seminar for U.S. and Latin American policymakers, businesspersons, and academics on opportunities in the region's most important environmental markets. During this event, HCET will make the official presentation of the market studies. This event will be coordinated with the Latin American and Caribbean Center and the Summit of Americas Center at Florida International University. 


\section{SUMMARY OF MAJOR ACCOMPLISHMENTS}

Throughout this project, the Hemispheric Center for Environmental Technology's goal was to initiate a comprehensive research program on sustainable development, environmental protection, and the market for environmental technologies in Latin America and the Caribbean. The data resulting from the work associated with this project has been entered into an information system which supplies useful and accurate data knowledge to interested parties. When relevant information has been found to be insufficient and/or not readily available, HCET has investigated, conducted research, and subsequently made this information available to the public.

During FY96, HCET completed numerous tasks to contribute to this body of knowledge. This initiative will continue throughout 1997. Highlights of FY96 are described below:

1. HCET has developed productive working relationships with numerous Latin American and Caribbean academic, private sector, and governmental institutions. Due to this collaboration, HCET is able to provide information regarding the status of economic, political, social, legal, and environmental situations in the Western Hemisphere. As these relationships continue to expand and flourish over the coming years, HCET will continue to be an important resource to organizations operating in this region;

2. HCET hosted the signing of the historic Implementing Arrangement between the Department of Energy of the United States of America and the National Atomic Energy Commission of the Argentine Republic for Technical Exchange and Cooperation in the Area of Radioactive and Mixed Waste Management;

3. Recognizing HCET's expertise in the Latin American and Caribbean environmental field, DOE's Office of Science and Technology (OST) designated HCET as its principal technology transfer agent for this region. This includes the Center's assuming a management role with respect to the aforementioned Implementing Arrangement, among other activities;

4. In recognition of HCET's expertise, HCET was asked to host the first Joint Coordinating Committee for Radioactive and Mixed Waste Management, established under the aforementioned Implementing Arrangement;

5. At the request of the U.S. Department of Energy, HCET translated DOE's remediation technology information cards from English into Spanish. These have allowed governmental and private sector organizations within Latin America and the Caribbean to become more familiar with the latest environmental technologies produced by U.S. industry;

6. HCET participated in Spectrum '96: An International Topical Meeting on Nuclear and Hazardous Waste Management. At this meeting, HCET presented four poster sessions and a full paper focusing on Latin America's environmental technology market. In addition, a panel discussion was held on this topic featuring representatives from HCET, Westinghouse Hanford Company, and speakers from Argentina and Mexico; and

7. HCET has contributed to the understanding of the global environmental technology market, through the commissioning of four comprehensive country studies in this area. These studies 
will provide accurate information on the environmental situation in each country and on the need for and status of existing environmental remediation projects. These studies will be extremely useful for organizations currently working in the region as well as for those wishing to enter the market.

HCET recognizes the need to continue to dedicate resources to the understanding of the environmental situation in Latin America and the Caribbean due to its invariably changing nature. New projects that will add to the growing database of knowledge are being conducted while the work associated with past projects is being updated and expanded. The hosting of $X$ change '97: The Global D\&D Marketplace and the inclusion of other countries in the environmental technology market study constitute examples of HCET's dedication to becoming a center of excellence in the area of environmental matters in Latin America and the Caribbean. 
American Embassy, U.S. and Foreign Commercial Service, Hazardous and Toxic Waste Disposat Control, and Remedial Equipment and Services. U.S. Department of Commerce, Mexico City, Mexico, 1995.

Ebadian, M.A. Decontamination and Decommission Project Technical Plan: Latin America's Decontamination and Decommissioning Needs. Hemispheric Center for Environmental Technology (HCET), Miami, January 1996.

Ministerio de Comercio Exterior de Colombia, FTAA -Free Trade Area of the Americas- 2005: Workshops Conclusions, Cartagena de Indias, March 18-21, 1996.

Robillard, David, The Market for Environmental Goods and Services in Mexico, prepared by Market Strategies International S.A. de C.V. for the Hemispheric Center for Environmental Technology, the Latin American and Caribbean Center, and the Summit of the Americas Center, Florida International University, Miami, (forthcoming). 



\section{APPENDIX A}

\section{SUGGESTED READING LIST}

Anderson, D., Environmental Policy and the Public Revenue in Developing Countries,: Working Paper No. 36, International Bank for Reconstruction and Development Department of Environment, Washington, D.C., 1990.

Arrow K., Bollin, B., Costanza, R., Dasgupta, P., Folke, C., Holling, C., Jansson, B., Levin, S., Maler, K., Perrings, C., and Pimenpel, D., "Economic Growth, Carrying Capacity, and the Environment," Science, Vol. 268, 1995, pp. 520-521.

Barret, S. "International Cooperation for Environmental Protection." In Economics of the Environment, Selected Readings. Edited by Robert Dorfman and Nancy S. Dorfman. W.W. Norton \& Company, New York, 1990.

Cairncross, F., Costing the Earth: The Challenge for Governments, the Opportunities for Business, Harvard Business School Press, Boston, 1993.

Ekins, P., C. Folke, and Costanza, R., "Trade, Environment and Development: The Issues in Perspective," Ecological Economics, Vol. 9, 1994.

International Bank for Reconstruction and Development (IBRD) and the International Monetary Fund (IMF) Development Committee, Environment, Growth, and Development, Paper No. 14, n.p., Washington, D.C., 1987.

Jaffe, A.B., Peterson, S., Partney P., and Stavins, R.. "Environmental Regulation and the Competitiveness of U.S. Manufacturing: What Does the Evidence Tell Us?" Journal of Economic Literature, Vol. XXXIII, 1995, pp. 132-163.

Organization for Economic Cooperation and Development (OECD), Economic Instruments in Solid Waste Management, OECD, Paris, 1981.

Pearce, D., "Economics and the Global Environmental Challenge," Millenium Journal of International Relations, Vol. 90, No. 3, 1990, pp. 365-388.

Pezzey, J., Economic Analysis of Sustainable Growth and Sustainable Development. Working Paper No. 15, International Bank of Reconstruction and Development (IBRD) Department of Environment, Washington, D.C., 1989.

Russell, C., "Economic Incentives in the Managment of Hazardous Waste," Columbia Journal of Environmental Law, Vol. 13, 1988, pp. 257-274.

Seldon T.M. and Song, D., Environmental Quality and Development: Is There A Kuznets Curve for Air Pollution. Department of Economics, Syracuse University, Syracuse, 1992.

Shafik, N., "Economic Development and Environmental Quality: An Econometric Analysis," Oxford Economic Papers, Vol. 46, 1994, pp. 753-773. 
Shafik N. and Bandyopadhyaya, S. "Economic Growth and Environmental Quality: Time Series and Cross-Country Evidence," Background Paper for the World Development Report . 1992, The World Bank, Washington D.C., 1992. 


\section{ENVIRONMENTAL INSTITUTIONS IN ARGENTINA, BRAZIL, AND MEXICO}

\begin{abstract}
ARGENTINA
MABEL HILDA MULLER, PRESIDENTE COMISION DE RECURSOS NATURALES Y CONSERVACION DEL AMBIENTE HUMANO H. CAMARA DE DIPUTADOS DE LA NACION RIOBAMBA 21, PISO 1, OF. 148/9 1025 BUENOS AIRES PHONE: (54-1) 954-1111/1113 (EXT. 2132) COMMENT: ENVIRONMENTAL COMMITTEE, LOWER HOUSE, ARGENTINE CONGRESS
\end{abstract}

DR. JAIME PAHISSA CAMPA COMISION NACIONAL DE ENERGIA ATOMICA AV. DEL LIBERATADOR 8250 CP 1429, BUENOS AIRES, ARGENTINA PHONE (54-1) 704-1435/1260

LIC. JORGE DOMINGUEZ, INTENDENTE MUNICIPALIDAD DE LA CIUDAD DE BUENOS AIRES

EDIFICIO MUNICIPAL, PISO I

1084 BUENOS AIRES

PHONE: (54-1) 331-2644; (54-1) 334-3816/1970

COMMENT: CITY HALL, FEDERAL DISTRICT

DR. CARO FIGUEROA MINISTRO DE TRABAJO Y SEGURIDAD SOCIAL MINISTERIO DE TRABAJO Y SEGURIDAD SOCIAL AV. LEANDRO N. ALEM 650, P.B. 1001 BUENOS AIRES

PHONE: (54-1) 331-3303/2945/5077 COMMENT: MINISTER OF LABOR AND SOCIAL SECURITY (FEDERAL)
NNG. MARIA JULIA ALSOGARAY SECRETARIA DE RECURSOS NATURALES Y AMBIENTE HUMANO (SRNAH) PRESIDENCIA DE LA NACION SAN MARTIN 459, PISO 1 PHONE: (54-1) 325-7679/80 COMMENT: SECRETARY OF NATURAL RESOURCES AND HUMAN ENVIRONMENT (FEDERAL)

DR. MARIO RODOLFO DEMARCO NAON, PRESIDENTE INSTITUTO NACIONAL DE CIENCIA Y TECNICAS HIDRICAS (INC Y TH) EMPALME AUT. RICHIERI Y RUTA $205 \mathrm{KM} 2,5$ 1804 EZEIZA, PROVINCIA DE BUENOS AIRES PHONE: (54-1) 480-9185/9073/0839 COMMENT: WATER SCIENCE AND TECHNOLOGY INSTITUTE NOTE: DR. DEMARCO NAON IS ALSO UNDERSECRETARY OF THE ENVIRONMENT. SRNAH.

SECRETARIA DE ENERGIA AV. PASEAO COLON 171, PISO 8, OF. 803 1063 BUENOS AIRES TEL: (1) 349-8003/5 FAX: (1) 343-6404

MINISTERIO DE ECONOMIA Y OBRAS Y SERVICIOS PUBLICOS HIPOLITO YRIGOYEN 250 1310 BUENOS AIRES PHONE: (54-1) 349-8801/5 COMMENT: MINISTER OF ECONOMY AND PUBLIC WORKS AND SERVICES 
NG. ANDRES BERNANTINOS LAFUENTE. PRESIDENTE

ABL ECOSYSTEM S.A.

CARLOS PELLEGRINI 1175, PISO 2, OF. B

1009 BUENOS AIRES -

PHONE: (54-1) 325-9671; (54-1) 322-4233

VICTOR GARIBOLDI, PRESIDENT

DECISION CONSULTORA S.R.L.

SARMIENTO 1674, PISO 7

1042 BUENOS AIRES

PHONE: (54-1) 382-7272/6763/5936

FAX: (54-1) 382-0688

ING. CARLOS J. SOZZANI, PRESIDENT CONSERSA, CONSULTORES DE SERVICIOS

S.A.

AV. BELGRANO 355, PISO 6

1092 BUENOS AIRES

PHONE: (54-1) 331-2615; (54-1) 342-2001

VIDA SILVESTRE

DEFENSA 245

1065 BUENOS AIRES

PHONE: (54-1) 343-3778/4086

COMMENT: PUBLISHED BY THE FUNDACIÓN

VIDA SILVESTRE ARGENTINA

(ARGENTINE WILDLIFE FOUNDATION)

EMPRESA Y MEDIO AMBIENTE

SARMIENTO 1452, PISO 1 "B"

1042 BUENOS AIRES

PHONE/FAX: (54-1) 372-9877/9870

DIRECTOR: DR. JORGE SANCHEZ

MEDIO AMBIENTE Y URBANIZACIÓN

AV. CORRIENTES 2835

1193 BUENOS AIRES

COMMENT: PUBLISHED BY THE INSTITUTO

NACIONAL DE MEDIO AMBIENTE Y

DESARROLLO

\section{BRAZIL}

MINISTERIO DO MEIO AMBIENTE

ESPLANADA DOS MINISTERIOS

BLOCO B, 5 ANDAR

70068-900 BRASILIA DF

TEL: $55 / 61 / 255-5857$

FAX: 55/61/321-5547

CONTACT: GARY SOARES DE LIMA, COORDINATOR

COMMENT: MINISTERIO DO MEIO AMBIENTE

IS THE BRAZILIAN MINISTRY FOR

ENVIRONMENT AND IS RESPONSIBLE FOR

ALL BRAZILIAN ENVIRONMENTAL POLICY.

CONSELHO NACIONAL DO MEIO AMBIENTE (CONAMA)

SAIN, AVENIDA NORTE, QUADRA 604, EDIFICIO SEDE DO IBAMA, SALA 54

70800-200 BRASILIA DF

TEL: $55 / 61 / 225-0564$

FAX: 55/61/226-4991

CONTACT: LEDA FERRER, MANAGER, SOLID

RESIDUES DEPARTMENT

COMMENT: CONAMA, THE NATIONAL ENVIRONMENTAL COUNCIL, IS RESPONSIBLE FOR THE COUNTRY-WIDE IMPLEMENTATION OF ENVIRONMENTAL PROGRAMS.

FEDERATION OF INDUSTRIES OF THE STATE OF SAO PAULO (FIESP)

DEPARTAMENTO DE MEIO AMBIENTE A USO DE SOLO

AVENIDA PAULISTA, 1313, 5 ANDAR, SALA 505

CEP 01311-923, SAO PAULO, SP

TEL: $55 / 11 / 251-3522 \times 237 / 267 / 268$

FAX: 55/11/284-3971

CONTACT: MARIA HELENA DE ANDRADE

ORTH, DIRECTOR OF ENVIRONMENT

DEPARTMENT.

COMMENT: FIESP IS THE LARGEST AND

MOST POWERFUL ASSOCIATION

REPRESENTING THE STATE OF SAO PAULO'S

INDUSTRIAL CONCERNS. 
ASSOCIACAO NACIONAL DOS FABRICANTES

DE FOLHAS DE FLANDRES (PROLATA)

AV. MORUMBI 8571 CJ 39

04703-004 SAO PAULO SP

TEL: $55 / 11 / 530-8296$

FAX: 55/11/531-6355

CONTACT: ROBERTO PINTO, PUBLIC

RELATIONS

COMMENT: PROLATA IS THE NATIONAL ASSOCIATION OF ROLLED-STEEL

MANUFACTURERS

ASSOCIACAO NACIONAL DOS APARISTAS

RUA BRIGADEIRO GAVIAO PEIXOTO 719

05078-000 SAO PAULO SP

TEL: 55/11/831-0044

FAX: 55/11/831-0044

CONTACT: MR. ANGELO DI FARNO,

PRESIDENT

COMMENT: ASSOCIACAO NACIONAL DOS

APARISTAS IS THE BRAZILIAN ASSOCIATION

OF PAPER SHREDDERS.

SEMCO RAL EQUIPAMENTOS AMBIENTAIS

LTDA.

RUA DOM AGUIRRE 438

04671 SAO PAULO SP

TEL: $55 / 11 / 523-9952$

FAX: $55 / 11 / 522-9952$

CONTACT: MR. EUGENIO SINGER, DIRECTOR

COMMENT: SEMCO RAL IS AN ENGINEERING

COMPANY REPRESENTING FOREIGN

RECYCLING EQUIPMENT MANUFACTURERS.

CONTEXTO CONSULTORIA EMPRESARIAL LTDA.

RUA VITORINO DE MORAES 38

04714-030 SAO PAULO SP

TEL/FAX: $55 / 11 / 524-8702$

CONTACT: WLADIMIR RODNEY PALERMO, DIRECTOR

COMMENT: CONTEXTO IS THE BRAZILIAN REPRESENTATIVE OF THE AMERICAN ENVIRONMENTAL CONSULTING COMPANY THE BASE CONSULTANT.
NUCLEAR AND ENERGETIC RESEARCH INSTITUTE

TRAVESSA R 400 - CID.UNIVERSITARIA

SAO PAULO - SP BRAZIL

PHONE OF ORGANIZATION: (011)211.6011

CABLE: 05.508-900

TELEX: (011) B3592 IPEN BR

FAX: (011)212.3546

CONTACT: VANIA CAIRO BORGHI

TITLE: HEAD OF THE DIVISION OF INTERCHANGE AND NUCLEAR ENGINEERI INSTITUTION TYPE: GOVERNMENT/INTERGOVERNMENTAL

QUIMICA E DERIVADOS

R. DR. GABRIEL DOS SANTOS 55

01231-900 SO PAULO SP

TEL: $55 / 11 / 826-6899$

FAX: $55 / 11 / 825-8192$

CONTACT: DENISARD GEROLA DA SILVA PINTO, DIRECTOR OF COMMERCIAL DEPARTMENT

COMMENT: QUIMICA E DERIVADOS IS A MAGAZINE THAT FOCUSES ON THE CHEMICAL AND PETROCHEMICAL INDUSTRY.

\section{CHILE}

EL MERCURIO S.A.P. SANTA MARIA 5542, LAS CONDES SANTLAGO, CHILE

TEL.: (562) 228-7048

FAX.: (562) 228-9262

CELULOSA Y PAPEL ASOCIACION TECNICA DE LA CELULOSA Y EL PAPEL

LINCOYAN 599, PISO 2

CONCEPCION, CHILE

TEL: (56 41) 237-679

CONTACT: HERNAN RUIZ C.

COMMENT: TRADE JOURNAL 
BANCO CENTRAL DE CHILE (CHILEAN

CENTRAL BANK)

AGUSTINAS 1180

SANTIAGO, CHILE

TEL: (562) 670-2000 -

FAX: (562) 698-4847

CONTACTS: ROBERTO ZAHLER, GENERAL MANAGER

JUAN FOXLEY, INTERNATIONAL MANAGER NICOLAS EYSAGUIRRE, ANALYSIS

DEPARTMENT MANAGER

CENTRO DE INFORMACION DE RECURSOS

NATURALES (CIREN)

(NATURAL RESOURCES INFORMATION

CENTER)

AV. MANUEL MONTT 1164, PROVIDENCIA

SANTIAGO, CHILE

TEL: (56-2) 223-6641

FAX: (56-2) 209-6407

CONTACT: ANA MARIA NAVES,

ENVIRONMENTAL AREA SUPERVISOR

CORPORACION NACIONAL DEL COBRE DE

CHILE (CODELCO-CHILE)

HUERFANOS 1270

SANTIAGO, CHILE

PURCHASING OFFICE

TEL: (562) 690-3242

FAX: (562) 690-3059

CONTACTS: FELIPE SANDOVAL, EXECUTIVE

MINISTERIAL VICE PRESIDENT

COMMENT: WORLD'S LARGEST COPPER

PRODUCING COMPANY, STATE-OWNED.

INSTITUTO DE SALUD PUBLICA (ISP)

(PUBLIC HEALTH INSTITUTE)

AV. MARATHON 1000, NUNOA

SANTIAGO, CHILE

TEL: (56-2) 239-1105

FAX: (56-2) 239-0862

CONTACT: MIGUEL CAMUS, ENVIRONMENTAL POLLUTION SECTION MANAGER
MINISTERIO DE BIENES NACIONALES (MBN)

(MINISTRY OF NATIONAL RESOLRCES)

JUAN ANTONIO RIOS 6

SANTIAGO, CHILE

TEL: (56-2) 633-9305; 633-9307

FAX: (56-2) 632-5223

CONTACT: SUSANA DEL CANTO,

ENVIRONMENTAL TECHNICAL UNIT

MANAGER

ASOCIACION DE INDUSTRIALES QUIMICOS (ASIQUIM)

(CHEMICAL INDUSTRY ASSOCIATION)

ANDRES BELLO 2777, OF. 501, PROVIDENCIA

SANTIAGO, CHILE

TEL: (56-2) 203-3350

FAX: (56-2) 203-3351

CONTACT: FRANCISCO MUZ, PRESIDENT

COLEGIO DE INGENIEROS DE CHILE A.G. (ASSOCIATION OF CHILEAN ENGINEERS)

AV. SANTA MARIA 0508

SANTIAGO, CHILE

TEL: (56 2) 777-9530

FAX: (56 2) 777-8681

FLUOR DANIEL CHILE S.A.

MARCHANT PEREIRA 221, PISO 7,

PROVIDENCIA

SANTIAGO, CHILE

TEL: $(56-2) 340-8000$

FAX: (56-2) 223-1025

CONTACT: CESAR CELLE, ENGINEERING

MANAGER

JORGE ARRUESTE, ENVIRONMENTAL

ENGINEERING SPECIALIST

LOGISTICA S. A.

AV. BRASIL 229

SANTIAGO, CHILE SEC 20-6B

RUT: $96691890-\mathrm{K}$

TEL: (56-2) 6987257

FAX: (56-2) 6728646

GENERAL MANAGER: MARCOS PAUVIF

BALBOA 
ESTUDIO Y GESTION AMBIENTAL LTDA.

AV. FRANCISCO BILBAO 4860

SANTIAGO, CHILE SEC 22-4D

RUT: $78545220-8$

TEL: (56-2) 2074796

FAX: (56-2) 2074796

PRESIDENT: MANUEL BAQUEDANO

EXECUTIVE DIRECTOR: TERESA

MONTECINOS

RESEARCH DIRECTOR: JORGE GREENE

BUSINESS DIRECTOR: RODRIGO CERDA

OPERATIONS DIRECTOR: PAOLA ESCOBAR

SEGA CONSULTORES AMBIENTALESI

BILBAO N 4860

LAS CONDES - CHILE

TEL/FAX: 2 - 2074796

CONSULTORES GESTORA DE INVERSIONES Y PROYECTOS LTDA. (CINPRO)

MERCED 332, OF. 83,

SANTIAGO, CHILE SEC 20-5E

RUT: $78208620-0$

TEL: (56-2) 6324927

FAX: (56-2) 6324923

GENERAL MANAGER: PASCALE DESBORDES

PAISAJES Y ECOSISTEMAS CHILE

ANDACOLLO 1573 DP. 803

SANTIAGO, CHILE

RUT: 2303627-4

TEL: (56-2) 2239004

FAX: (56-2) 2239004

GENERAL MANAGER: EDUARDO GOLDFARB
MAIN CONSTRUCCIONES LTDA.

PJE. LIBARI 856 DP. C

QUILPUE, CHILE

RUT: 78042340-4

TEL: (56-32) 923908

FAX: (56-32) 923908

SENES CHILE S.A. CONSULTORIAS

AMBIENTALES

AV. VITACURA 3900, OF. 707

SANTIAGO, CHILE

RUT: $96792480-6$

TEL: (56-2) 2075486

FAX: (56-2) 2075486

LEGAL REPRESENTATIVE: LEOPOLDO

BUSTOS INDA

SOCIEDAD DE ESTUDIOS Y POLITICA

ECOLOGICA Y DESARROLLO LTDA. (IEP)

AV. SEMINARIO 776,

SANTIAGO, CHILE SEC 29-1B

RUT: $78110720-4$

TEL: (56-2) 2746192

FAX: (56-2) 2234522 


\title{
THE ENVIRONMENTAL TECHNOLOGY MARKET \\ IN LATIN AMERICA: AN OVERVIEW
}

\author{
Jairo Valverde-Bermúdez \\ Hemispheric Center for Environmental Technology \\ Latin American and Caribbean Center \\ Florida International University \\ University Park, DM 353 \\ Miami, FL 33199 \\ (305) $348-2894$
}

\begin{abstract}
Latin America has experienced dramatic changes during the last fifteen years. These changes range from the return of democratic governance, economic reform, and stabilization to the embrace of free trade and an increasingly acute sense of the need for environmental regulation, protection, and remediation. This new concern for the environment represents a dramatic shift in the perceptions and policies of many countries in the Western Hemisphere. Environmental issues have evolved from being an almost peripheral concern 10 years ago to $\mathrm{a}$ top priority item in most govemments' agenda today. More importantly, the business sector has come to realize the potential value of the market for environmental goods and services, and many business concerns are actively pursuing this new market. This paper will provide a general overview of the approach several Latin American countries are taking with respect to environmental protection and remediation. In this discussion, special attention will be paid to economic reform and legislative processes.
\end{abstract}

\section{INTRODUCTION}

Economic reform and recovery have swept throughout Latin America since the mid- 1980s, when most countries in the region embarked upon market reform programs, fiscal and monetary stabilization, and the privatization of state-owned companies. The success of these programs can readily be observed in the improved economic performance witnessed by most countries. This growth is best illustrated, perhaps, by Argentina and Chile's high gross domestic product (GDP) growth rates of 8.7 and 10.4 percent, respectively, in 1992, and 5.0 and 6.0 percent, respectively, in 1993. Latin America's economic ascendance is not only manifest in GDP and income growth rates but also in the increasing importance of its market to the United States.
The region's total imports from the United States grew on average 12 percent per year between 1983 and 1993, from $\$ 25.5$ billion in 1983 to $\$ 78.5$ billion in 1993. Latin America's exports to the United States grew at an annual rate of 7 percent during this period, from \$41.4 billion in 1983 to $\$ 72.6$ billion in 1993.[1]

These changes have not only restored growth and investor confidence in the economies of the Western Hemisphere, but they also created new business opportunities in most sectors of the economy. These new opportunities include those in areas related to nuclear and hazardous waste management.

\section{NUCLEAR WASTE MANAGEMENT IN LATIN AMERICA}

Currently, Argentina possesses one of the most fully developed nuclear program in Latin America. Argentina has two operational nuclear power plants, Atucha- 1 and Embalse. Atucha-1, the first nuclear power plant to open in Latin America, began operating in 1974. Today, it has a production capacity of 335 megawatts. Embalse, a 600 megawatt plant, began operation in 1983. Together, they represent slightly less than 6 percent of Argentina's electric generation capacity, which is currently estimated at 17 gigawatts. A third plant, Atucha-2, is scheduled to reach initial criticality by May 1997 and start commercial operation by December 1997 with a 692 megawatt capacity.[2]

Because Argentina's program is relatively young compared to nuclear programs in the United States, Europe or Japan, nuclear waste management does not yet exhibit the salience it has in industrial nations. According to official reports, current nuclear residue production does 
not exceed the in-situ storage capacity of the plants producing energy.

Nonetheless, Argentine authorities expect the need for a more efficient nuclear industry and for nuclear waste management to grow in the future. Officials are working to develop the necessary infrastructure to attract private capital to this area. Their plans include the reorganization and privatization of the National Atomic Energy Commission (Comisión Nacional de Energía Atómica, CONEA). To this end, they have created a National Regulatory Authority for Nuclear Energy (Ente Nacional Regulador, ENRE) to supervise and regulate this sector. This new Regulatory Authority will be responsible for enforcing all regulations pertaining to the startup and operation of reactors as well as the rules on the transport of radioactive materials and radiological safety. Government officials have also approved the creation of Nucleoeléctrica Argentina S.A., a private company that will take over operation of the Atucha-1 and Embalse plants. In addition, Nucleoeléctrica will assume responsibility for the completion of the Atucha-2 plant. [3]

Argentina's future nuclear waste management needs include the identification and development of a nuclear waste repository. A likely candidate is Gastre, an area located approximately 900 miles south of Buenos Aires, the nation's capital and largest city. Scientists claim the site rests on a bed of solid, pure granite; test holes have been drilled in the granite to measure its capacity to prevent waste from seeping into local water systems. [4] Although the issue of using Gastre as a dump site has been controversial, CONEA insists it is one of the safest and most suitable locations in Argentina for the construction of a radioactive waste storage site.[5]

Given Argentina's push toward the privatization of the nuclear industry, it is reasonable to expect that the construction of the dump site, regardless of its final location, will include an international contract bidding process, thus opening investment opportunities for intemational companies with the capacity to provide the goods and services required by the government of Argentina.

\section{HAZARDOUS WASTE MANAGEMENT IN LATIN AMERICA}

Hazardous waste management is one of the most pressing environmental problems in Latin America. The severity of the problem and the governmental responses to it vary greatly throughout Latin America. Mexico and Chile have made the greatest advances in this field, particularly in the creation of a legal framework and regulatory agencies that facilitate and encourage environmentally sound techniques for the disposing of hazardous waste. Therefore, the conditions for private investment in both countries are very favorable, as evidenced by the growing number of firms providing environmental remediation and consulting services in each of these markets.

Mexico's environmental sector presents some of the best opportunities as well as some of the most daunting challenges in the Westem Hemisphere. On the one hand, Mexico's environmental protection agency, the National Institute of Ecology (Instituto Nacional de Ecologia, INE), estimates that only 10 percent of all hazardous waste generated in Mexico is disposed of adequately. This clearly points to the need for environmental remediation in Mexico. Such a need should generate a large demand for waste characterization, monitoring and treatment services. In addition, training and consulting services are in demand as Mexican companies try to comply with existing or with new environmental regulations.

The demand for environmental technology solutions generated by industrialization and degradation will be complemented by new legislation that is pending in the Mexican congress as of this writing. In addition, the environmental agreements signed as part of the North American Free Trade Agreement (NAFTA) require Mexican companies as well as foreign companies based in Mexico to comply with stricter environmental standards and move toward the harmonization of these standards.

The United States Embassy in Mexico projects that the market for environmental technology goods and services will grow 4.7 percent to $\$ 408.8$ million in 1996 [6]. The Embassy also expects the export of U.S. hazardous waste management equipment and services to grow by 7.5 percent in 1996, permitting U.S. companies to control 85 percent of Mexican imports.

However, one of the most difficult problems to address in Mexico is the Mexican authorities' inability to enforce existing environmental regulations in a consistent manner. Although the government's efforts to strengthen law-enforcement institutions have increased the capacity of institutions such as INE, the structure of Mexican industry makes it difficult to pursue environmental programs due to the fact that Mexico's worst polluters are small-sized companies. Where these are scattered, environmental pollution control becomes costly and 
difficult. In addition, jurisdictional conflict among agencies impedes proper compliance, monitoring, and law enforcement. For example, the Secretariat of Communications and Transportation (Secretaria de Comunicacines y Transporte) allows hazardous waste transportation companies to operate even if they have not received authorization to operate from the $\mathrm{NE}$. As a result, firms that often fail to ensure that hazardous wastes arrive at treatment or confinement sites are permitted to operate freely.

Chile, on the other hand, is considered by many as Latin America's "model economy." As the leading free trader and open economy in Latin America, Chile has aggressively pursued export-led growth and private sector participation in the economy. It has experienced steady GDP per capita growth for the last ten years, varying from a low 1.6 percent in 1990 to an astounding 9.3 percent in 1992.

As is the case with any booming economy, most sectors of the Chilean economy are benefiting from economic growth as the demand for goods and services increases. The environmental technology sector is one of the main beneficiaries of economic liberalization and growth since industries that produce hazardous and other environmentally harmful wastes are more willing and have a greater capacity to pay for the costs of pollution prevention and environmental remediation during times of economic expansion. In Chile, this process will be aided by the current wave of environmental legislation and regulation.

In light of the above-mentioned factors (economic growth and environmental legislation), we can safely infer the market for environmental technology goods and services in Chile will closely resemble the growth pattern of the whole economy. In fact, it is also quite possible that the growth of the environmental technology market will exceed the country's overall GDP growth rate as a result of the additional stimulus for investment in this sector arising from new legislation.

Chile's environmental framework is provided by the Basic Environmental Law (Ley de Bases del Medio Ambiente), approved in 1994. The Basic Environmental Law is to serve as a guideline for the creation of future environmental regulations on the basis of the principles of prevention, responsibility, efficiency, public participation, assessing pollution costs to the polluter, and the gradual elevation of standards and requirements for various production processes [7]. The prevention principle aims primarily at promoting education and training of both producers and consumers, while the principle of responsibility stipulates in general terms the legal accountability of those responsible for environmental damage and any corollary damage to society. The principle of efficiency emphasizes the use of the market to use and allocate resources rationally. The principle of participation is, to some extent, the most significant, for it concedes environmental legislation will be difficult to implement or rendered ineffective in the absence of a consensus and a change of attitude by all members of society.

It is important to note that proper enforcement of the Basic Environmental Law will hinge on two factors: the approval and enactment of new environmental laws and the strengthening of environmental oversight agencies. According to the U.S. Department of Commerce, the latter is a more serious problem with respect to the laws' impact on the market for environmental technology goods and services, especially considering environmental lawenforcement agencies such as the National Commission for the Environment (Comisión Nacional para el Medio Ambiente, CONAMA) possess neither sufficient staff nor the technical expertise to fulfill their mission.[8]

Other nations in the Westem Hemisphere, including those in Central America and the Caribbean, lag behind in market development, regulatory mechanisms, and environmental legislation. However, in the government and the business community a growing awareness exists of the need to push for and implement reforms in this sector. This change will open investment opportunities to even more companies specializing in the disposal of hazardous waste.

\section{CONCLUSIONS}

The most important factor that characterizes the markets for environmental goods and services in Latin America is that they are not yet heavily reliant on the individual consumer market. Instead, these markets are geared to large-scale projects, such as the cleanup of the Matanza-Riachuelo Basin in Argentina. These monumental projects are extremely dependent on lending from intemational financial institutions (IFIs) such as the World Bank and the InterAmerican Development Bank. In addition, the environmental market and the investment opportunities it entails depend on well-defined legislation and strict law enforcement.

These markets will grow, however, as more govemments take advantage of institutional strengthening programs sponsored by IFIs. Moreover, as governmental 
and nongovemmental educational programs on environmental protection become widespread and begin to affect the behavior of different actors in society, it is likely the environmental market will witness the emergence of a consumer market that relies on the laws of supply and demand rather than on legislation and regulation.

Companies wishing to enter the environmental market in Latin America will need to keep abreast of the rapidly changing regulatory framework in the countries of the region. This process can be facilitated by the formation of partnerships (or some other contractual relationship) with well-established environmental engineering firms in the

- target markets.

\section{REFERENCES}

[1] USAID 1994 Database. Latin American and the Caribbean: Selected Economic and Social Data, Available on the World Wide Web at http://lanic.utexas.edu/la/region/aid/aid94.

[2] Nuclear News, Vol. 38, (3), March 1995.

[3] Latin American Law and Business Report, Vol. 3, N12, December 31, 1995.

[4] Nash, Nathaniel C, "Gastre Joumal: For the Desperate, Nuclear Waste Isn't Dreadful," The New York Times, p. A4, February 24, 1994.

[5] British Broadcasting Corporation, BBC Summary of World Broadcasts, April 22, 1995.

[6] American Embassy, U.S. and Foreign Commercial Service. Hazardous and Toxic Waste Disposal Control and Remedial Equipment and Services,. Mexico City, Mexico.

[7] Heitnamm, Carol. "Chile: Environmental Consulting Services," National Trade Data Bank, November 21, 1995.

[8] Trade Promotion Coordinating Committee, Environmental Trade Working Group. The Chilean and Argentine Environmental Technologies Market, U.S. Department of Commerce, Intemational Trade Administration 1994. 